\title{
Acute Unilateral Ureteric Obstruction in Young Men With High Serum Creatinine: Is It True or False Renal Impairment?
}

\author{
Mohamed El-Shazly ${ }^{\mathrm{a}, \mathrm{e}}$, Mohamed Aziz ${ }^{\mathrm{a}}$, Mohamed Selim ${ }^{\mathrm{a}}$, Atef Badawi ${ }^{\mathrm{a}}$, Maher Gawish ${ }^{\mathrm{b}}$, \\ Ali Al-Amiric, Adel Allam ${ }^{c}$, Osama Ragab ${ }^{\mathrm{d}}$, Marwa Elbedwihy ${ }^{\mathrm{d}}$
}

\begin{abstract}
Background: Acute unilateral ureteric obstruction, with normal contralateral kidney, is occasionally accompanied by a rise of serum creatinine. Urgent drainage is usually performed to restore normal renal function. However, there is a growing evidence in literature that this rise of serum creatinine is false (pseudo renal failure) due to absorption of urine with its high creatinine. This is possibly through back flow into venous and lymphatic vessels. This hypothesis can render urgent intervention in these circumstances unnecessary. Our aim was to measure global renal function by measuring estimated renographic glomerular filtration rate (GFR) to determine if there is a real impairment of renal function or not in this clinical scenario.
\end{abstract}

Methods: It is a prospective study over 3 years (2012 - 2015). All patients with acute unilateral ureteric obstruction due to ureteric stones with normal contralateral kidney and high serum creatinine $>140$ $\mathrm{mmol} / \mathrm{L}$ were included in our study. All patients were diagnosed by abdominal ultrasonography and non-contrast computed tomography (CT). Estimated GFR (eGFR) was measured using DTPA isotope renography on admission. Serum creatinine measurement and DTPA were repeated 2 weeks after intervention or after spontaneous passage of stones.

Results: Fifty-three patients (all males) were enrolled in the study. The mean age was $36.43 \pm 9.2$ years. The mean serum creatinine on admission was $178.7 \pm 14.83 \mu \mathrm{mol} / \mathrm{L}$ (normal range for males: 70 $120 \mu \mathrm{mol} / \mathrm{L})$. The mean eGFR on admission was $95.04 \pm 15.41 \mathrm{~mL} /$ min (normal range for males: $75-125 \mathrm{~mL} / \mathrm{min}$ ). Thirteen patients passed stones on medical expulsive therapy without intervention. Thirty-one patients underwent double $\mathrm{J}$ insertion and nine patients underwent ureteroscopy with stones removal or disintegration. The mean serum creatinine after treatment was $107.5 \pm 6.5 \mu \mathrm{mol} / \mathrm{L}$. The

Manuscript accepted for publication August 29, 2016

aUrology Department, Menoufia University, Egypt

bUrology Department, Alazhar University, Assiut, Egypt

'Urology Department, Farwaniya Hospital, Kuwait

${ }^{\mathrm{d} N u c l e a r}$ Medicine Department, Cairo University, Egypt

${ }^{e}$ Corresponding Author: Mohamed El-Shazly, Urology Department, Menoufia

University, Egypt. Email: mshazly2001@yahoo.com

doi: http://dx.doi.org/10.14740/wjnu276w mean eGFR after drainage or after passage of stones was $94.45 \pm 6.37$ $\mathrm{mL} / \mathrm{min}$. The difference between eGFR on admission and eGFR after passage of stones or after intervention was statistically insignificant $(\mathrm{P}>0.05)$.

Conclusions: Rise of serum creatinine in patients with acute unilateral ureteric obstruction is not associated with decreased renographic eGFR. Renal impairment in these circumstances is not a true impairment.

Keywords: Unilateral; Ureteric; Obstruction; False; Creatinine

\section{Introduction}

Elevated serum creatinine is used as a marker of impaired renal function [1]. Acute rise of serum creatinine indicates acute kidney injury (AKI) [2]. Acute bilateral ureteric obstruction is a common cause of AKI due to decreased glomerular filtration rate (GFR) and renal plasma flow with decrease of the optimal function of both kidneys [3]. Acute unilateral ureteral obstruction (AUUO) is a common presentation in clinical practice and mostly due to obstructing ureteric stone [4]. In AUUO, elevated serum creatinine is considered by some as AKI and consequently, urgent intervention is usually performed and conservative medical expulsive therapy (MET) is not recommended [5]. Urine has high levels of creatinine $(20-25 \mathrm{mg} /$ $\mathrm{kg} /$ day, roughly $1,575 \mathrm{mg} /$ day for a $70-\mathrm{kg}$ male) [6]. As high as $18 \%$ of AUUO may present with urine extravasation due to increased intrapelvic pressure. Absorption of extravasated urine or obstructed urine in AUUO into circulation elevates serum creatinine levels $[7,8]$. Recently, published animal study proved that in AUUO, back flow of obstructed urine into venous and lymphatic vessels causes elevation of serum creatinine. Accordingly, this rise of serum creatinine is considered a false renal impairment (pseudo renal failure) due to absorption of obstructed urine with its high creatinine levels [9].

Renal function can be estimated through measurement of GFR. This can be done through different methods as measurement of intrinsic creatinine clearance, from serum creatinine using the Cockcroft-Gault equation and through isotope renography using Tc-99m-DTPA $[1,10]$. In AUUO, high serum creatinine may affect estimation of renal function and GFR using 
Table 1. Clinical and Radiological Findings

\begin{tabular}{|c|c|c|}
\hline Variant & Numbers & Pvalue \\
\hline \multicolumn{3}{|l|}{ Number (total number: 53 cases) } \\
\hline Males & $53(100 \%)$ & \\
\hline Females & 0 & \\
\hline Right & $27(50.9 \%)$ & \\
\hline Left & $26(49.1 \%)$ & \\
\hline Serum creatinine $(\mu \mathrm{mol} / \mathrm{L})$ & & $<0.05$ \\
\hline On admission & $178.7 \pm 14.83$ & \\
\hline After drainage or stone passage & $107.5 \pm 6$ & \\
\hline Site of the stone & $41(77.3 \%)$ & \\
\hline Lower third ureter & $7(13.2 \%)$ & \\
\hline Middle third ureter & $5(9.5 \%)$ & \\
\hline \multicolumn{3}{|l|}{ Upper third ureter } \\
\hline eGFR (mL/min) & & $>0.05$ \\
\hline On admission & $95.04 \pm 15.41$ & \\
\hline After drainage or stone passage & $94.45 \pm 6.37$ & \\
\hline
\end{tabular}

either intrinsic creatinine clearance or from serum creatinine using the Cockcroft-Gault equation. However, estimation of GFR using Tc-99m-DTPA does not need blood or urine sampling and will not be affected by the rise of serum creatinine in this clinical scenario [11].

To our knowledge, there is no clinical study in the literature to prove or disprove this hypothesis.

Our aim was to measure global renal function by measuring eGFR to determine if there is a real impairment of renal function or not.

\section{Patients and Methods}

It is a prospective study over 3 years (2012 - 2015). It included patients from 25 to 45 years old. All patients with unilateral ureteric obstruction with normal contralateral kidney and high serum creatinine $>140 \mathrm{mmol} / \mathrm{L}$ were included in our study. $\mathrm{Pa}-$ tients with known previous renal impairment and contralateral hydronephrosis or medically diseased kidney were excluded from the study. All patients were diagnosed by abdominal ultrasonography and non-contrast computed tomography (CT). Demographic variables and preoperative routine laboratory tests including serum creatinine were recorded. eGFR was measured using Tc-99m-DTPA isotope renography on admission. Serum creatinine measurement and Tc-99m-DTPA were repeated 2 weeks after intervention or after spontaneous passage of stones. Patients meeting the criteria for MET were given standard treatment in the form of NSAIDs and $\alpha$-blockers till spontaneous passage of stone or intervention was indicated. Surgical intervention was done either due to failed MET or other causes like persistent pain or patient preference. Surgical intervention was done in the form of ureteral stenting with or without stone extraction.
Statistical analysis was done using paired samples test to compare creatinine and eGFR before and after relief of obstruction.

\section{Compliance with ethical standards}

We declare that we acted ethically regarding research involving human participants and informed consent. Approval of institutional board review was taken.

\section{Results}

Fifty-three patients (all males) were enrolled in the study. The mean age was $36.43 \pm 9.2$ years. Obstruction was on the right side in 27 patients $(50.9 \%)$. Thirty-seven patients had mild hydronephrosis $(69.8 \%)$ and 16 patients had moderate hydronephrosis $(30.2 \%)$. Forty-one patients had stone in the lower ureter $(77.3 \%)$, seven patients $(13.2 \%)$ had stone in middle third ureter and five patients $(9.5 \%)$ had stone in the upper ureter. The mean stone size was $9.1 \pm 5.3 \mathrm{~mm}$ (range from 4 to 15 $\mathrm{mm})$. Twenty patients $(37.8 \%)$ had stone $<6 \mathrm{~mm}$. Thirty-three patients $(62.2 \%)$ had stones more than $6 \mathrm{~mm}$. The mean serum creatinine on admission was $178.7 \pm 14.83 \mu \mathrm{mol} / \mathrm{L}$ (normal range for males: $70-120 \mu \mathrm{mol} / \mathrm{L}$ ). The mean serum creatinine after treatment was $107.5 \pm 6 \mu \mathrm{mol} / \mathrm{L}$. Differences in mean serum creatinine in admission and after passage of stone or treatment were statistically significant $(\mathrm{P}<0.05)$. Thirteen patients passed stones on MET without intervention. Thirty-one patients underwent double $\mathrm{J}$ insertion and nine patients underwent ureteroscopy with removal or disintegration. The mean eGFR on admission was $95.04 \pm 15.41 \mathrm{~mL} / \mathrm{min}$ (normal range for males: 75 - $125 \mathrm{~mL} / \mathrm{min}$ ). The mean eGFR after drainage or after passage of stones was $94.45 \pm 6.37 \mathrm{~mL} / \mathrm{min}$. This difference was statistically insignificant $(\mathrm{P}>0.05)$ (Table 1$)$. The mean hospital stay was $2.5 \pm 1.5$ days.

\section{Discussion}

AUUO is a common clinical scenario. It is commonly due to obstructing stone, less commonly due to trauma, iatrogenic, malignancy or endometriosis $[12,13]$. AUUO may be associated with a rise in serum creatinine levels, which raises the concern for AKI secondary to the obstruction. Urgent intervention in the form of ureteric stenting, percutaneous nephrostomy insertion or urgent ureteroscopy is often recommended [14]. It is commonly explained by urologist to be caused by use of NSAIDs, dehydration or due to renin angiotensin effect [15]. Such impairment if true will be detected through measurement of GFR. Measurement of GFR using Tc-99m-DTPA is commonly used and does not need blood or urine sampling [11]. There is a growing evidence from literature that renal impairment in AUUO is due to absorption of obstructed urine with its high creatinine back to systemic circulation. This is considered false renal impairment with normal GFR [9]. In our study, we measured renal function through measurement of eGFR using 
Tc-99m-DTPA. From our results, differences between eGFR on admission and after passage of stone or relieve of obstruction were non-significant. Our results support the hypothesis of false impairment in this clinical scenario. This may change practice in the future as there is no need to embark to urgent intervention and so, continuing MET is justifiable. Larger well-designed studies may be needed in the future to draw firm conclusion.

\section{Conclusions}

Rise of serum creatinine in patients with AUUO is not associated with decreased renographic eGFR. Our data suggest that renal impairment in these circumstances is not a true impairment.

\section{Conflicts of Interest}

The authors declare that they have no conflicts of interest.

\section{References}

1. Cockcroft DW, Gault MH. Prediction of creatinine clearance from serum creatinine. Nephron. 1976;16(1):31-41.

2. Bellomo R, Kellum JA, Ronco C. Acute kidney injury. Lancet. 2012;380(9843):756-766.

3. Klahr S. Urinary tract obstruction. Semin Nephrol. 2001;21(2):133-145.

4. Picozzi SC, Marenghi C, Casellato S, Ricci C, Gaeta M, Carmignani L. Management of ureteral calculi and medical expulsive therapy in emergency departments. J Emerg Trauma Shock. 2011;4(1):70-76.

5. Nakada SY, Hsu THS. Campbell, Campbell-Walsh urology / editor-in-chief, Alan J. Wein ; [editors, Louis R. Kavoussi ... et al.]. 10th ed. Philadelphia, PA: Elsevier Saunders. 2012:1163-1164.

6. Azotemia. http://emedicine.medscape.com/article/238545- overview.

7. Kosehan D, Akin K, Topcu A, Koktener A, Cakir B, Teksam M. Spontaneous urinary extravasation: detection rate with 64-row multidetector computed tomography in patients presenting with acute abdomen. Emerg Radiol. 2013;20(4):273-277.

8. Hinman F, Jr. Peripelvic extravasation during intravenous urography, evidence for an additional route for backflow after ureteral obstruction. J Urol. 1961;85:385-395.

9. Rosenzweig B, Pinthus JH, Kleinmann N, Joffe E, Erlich T, Fridman E, Winkler H, et al. The relative contribution of urine extravasation to elevate plasma creatinine levels in acute unilateral ureteral obstruction. Can Urol Assoc J. 2015;9(7-8):E428-433.

10. Itoh K. Comparison of methods for determination of glomerular filtration rate: Tc-99m-DTPA renography, predicted creatinine clearance method and plasma sample method. Ann Nucl Med. 2003;17(7):561-565.

11. Prigent A, Cosgriff P, Gates GF, Granerus G, Fine EJ, Itoh $\mathrm{K}$, Peters $\mathrm{M}$, et al. Consensus report on quality control of quantitative measurements of renal function obtained from the renogram: International Consensus Committee from the Scientific Committee of Radionuclides in Nephrourology. Semin Nucl Med. 1999;29(2):146-159.

12. Singh I, Strandhoy JW, Assimos DG. Campbell-Walsh Urology. 10th ed. Wein AJ, Kavoussi LR, Novick AC, Partin AW, Peters CA, editors. Philadelphia, PA: Elsevier Saunders; 2012:1087-1088.

13. Choi JI, Yoo JG, Kim SJ, Lee HN, Kim MJ. Acute Renal Failure due to Obstructive Uropathy Secondary to Ureteral Endometriosis. Case Rep Obstet Gynecol. 2015;2015:761348.

14. Turk C, Knoll T, Petrik A, Sarica K, Skolarikos A, Straub M, Seitz C. Guidelines on Urolithiasis. uroweb.org/wpcontent/uploads/22-Urolithiasis_LR.pdf.

15. Al-Ani A, Al-Jalham K, Ibrahim T, Majzoub A, AlRayashi M, Hayati A, Mubarak W, et al. Factors determining renal impairment in unilateral ureteral colic secondary to calcular disease: a prospective study. Int Urol Nephrol. 2015;47(7):1085-1090. 